\title{
Circulating high molecular weight IgG fibronectin complexes in myeloproliferative disorders
}

T P Baglin, S M Price, B J Boughton

\begin{abstract}
The plasma of patients with myeloproliferative diseases was examined by polyethylene glycol (PEG) precipitation, analytical ultracentrifugation, and immunoaffinity chromatography for the presence of high molecular weight complexes of IgG and fibronectin. Abnormal circulating high molecular weight material was identified by ultracentrifugation in all patients. This was precipitated by PEG and was shown by exclusion chromatography to contain IgG in a high molecular weight form. Examination of plasma by immunoaffinity chromatography supported previous evidence for complex formation between IgG and fibronectin. These findings are further evidence that abnormal high molecular weight IgG complexes are a prominent feature of myeloproliferative disorders and implicate IgG fibroectin complex formation.
\end{abstract}

The serum of patients with primary myelofibrosis yields positive results in a variety of assays of immune complexes. ${ }^{1-4}$ These findings have been attributed to the presence of high concentrations of circulating immune complexes, though the composition of any high molecular weight antigen-antibody complexes has not yet been established. Increased concentrations of polyethylene glycol precipitable IgG (PEG IgG) are suggestive of circulating high molecular weight forms of IgG in patients with primary myelofibrosis, and their demonstration in both primary proliferative polycythaemia and essential thrombocythaemia indicates a common underlying pathophysiology. ${ }^{5}$ A negative correlation between plasma concentrations of PEG IgG and fibronectin, and the high PEG precipitability of native plasma fibronectin compared with purified protein, suggests that some fibronectin may exist as a high molecular weight complex with IgG in the plasma of these patients. ${ }^{5}$ The purpose of this study was to establish the presence of high molecular weight complexes in the plasma of patients with myeloproliferative disorders and to determine if these consist of complexed IgG and fibronectin.

\section{Methods}

Five patients with myeloproliferative diseasetwo with primary myelofibrosis and three with primary proliferative polycythaemia - and five healthy controls were investigated. The five patients were selected from a larger group of previously reported patients ${ }^{5}$ on the basis that none had received chemotherapy or transfusion of blood products in the three months preceding the study.

\section{POLYETHYLENE GLYCOL (PEG) PRECIPITATION}

Proteins were precipitated from plasma anticoagulated with EDTA by $2 \%$ PEG (molecular weight 6000) at $4^{\circ} \mathrm{C}$. The precipitate was washed in $2 \%$ PEG, resuspended in saline, and the precipitated IgG quantitated by radial immunodiffusion. Immunoprecipitation of PEG precipitated IgG was determined from a plot of immunoprecipitated reference standard IgG concentrations. Thus values should be regarded as $\mathrm{mg}$ equivalents because enhanced immunoprecipitation of macromolecules or complexed proteins leads to underestimation when concentrations are calculated from a standard plot derived from immunoprecipitation of low molecular weight native proteins.

\section{EXCLUSION CHROMATOGRAPHY}

A gel column of sepharose 4B (Pharmacia Ltd) was equilibrated with $50 \mathrm{mM}$ TRIS-HCl (pH7.5) and calibrated with proteins of known molecular weight. Protein elution was recorded by ultraviolet absorption at $280 \mathrm{~nm}$. Samples were centrifuged at $1000 \times g$ for 10 minutes, filtered through a $2 \mu \mathrm{m}$ filter to remove any particular debris, and applied to the gel in filtered, deaerated TRIS- $\mathrm{HCl}$ buffer. The eluted fractions were analysed for individual proteins by radial immunodiffusion in gels containing appropriate antisera ("The Binding Site Ltd” Vincent Drive, Birmingham).

\section{ANALYTICAL ULTRACENTRIFUGATION}

Samples were centrifuged at $100000 \times g$ at $20^{\circ} \mathrm{C}$ in an MSE Centriscan 75 analytical ultracentrifuge. The analytical cells were scanned at four minute intervals against a phosphate buffered saline reference solution and sedimentation was observed by Schlieren optics. Sedimentation coefficients were calculated from a minimum of three sedimentation distances per sample. 


\section{AFFINITY CHROMATOGRAPHY}

Affinity gels were prepared according to the method of Axen et al. ${ }^{6}$ Cyanogen bromide activated sepharose 4B was coupled to substrate and uncoupled protein removed by washing in carbonate buffer. Any remaining active groups were blocked with molar ethanolamine ( $\mathrm{pH} 9 \cdot 0)$. The gel was then repeatedly washed in alternating carbonate buffer and $0 \cdot 1 \mathrm{M}$ acetate buffer and stored at $4^{\circ} \mathrm{C}$ in $1 \%$ azide. Before use gels were packed into polypropylene columns and equilibrated with $50 \mathrm{mM}$ TRIS-HCl. Loading and elution of gels was performed at a constant flow rate and protein elution monitored by ultraviolet absorption at $280 \mathrm{~nm}$. Individual proteins were identified and quantitated by rocket immunoelectrophoresis using precipitating antibodies ("The Binding Site Ltd.", Vincent Drive, Birmingham).

Affinity gels were prepared with gelatin, arginine, and sheep anti-human fibronectin. A fibronectin coupled sepharose gel was made from fresh human plasma fibronectin, prepared with the gelatin and arginine gels according to the method of Vuento and Vaheri. $^{7}$

\section{Results}

ANALYSIS OF PEG PRECIPITATES BY EXCLUSION CHROMATOGRAPHY

Fresh PEG precipitates were fractionated by exclusion chromatography and the IgG content of each fraction was measured to determine the molecular weight profile of PEG precipitated IgG. Fractionation of PEG precipitate from case 4 is shown in the figure and compared with

\footnotetext{
Molecular weight analysis by exclusion chromatography of purified IgG (above) and $P E G$ precipitated IgG from case 4 .
}
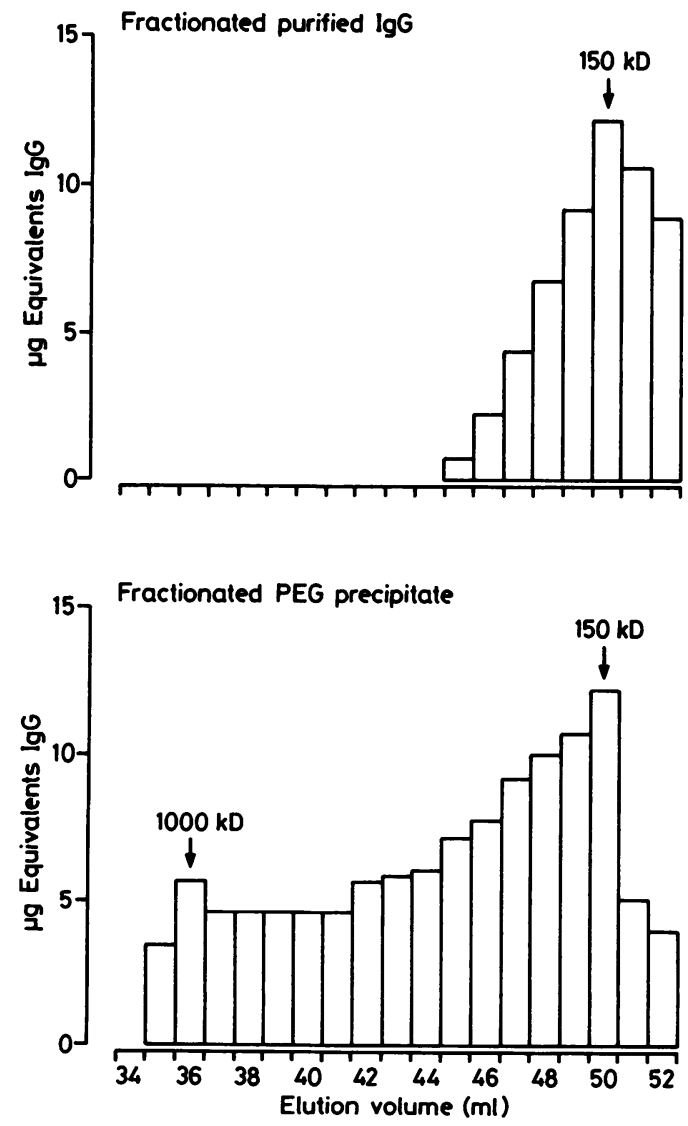

Table 1 Sedimentation coefficients and number of identifiable individual sedimentation peaks from examination of normal and patient plasmas and PEG precipitates by analytical ultracentrifugation

\begin{tabular}{|c|c|c|c|}
\hline Subject & $\begin{array}{l}\text { Number of } \\
\text { peaks }\end{array}$ & $\begin{array}{l}\text { Sedimentation } \\
\text { coefficients }\end{array}$ & $\underset{(m g / l)}{P E G \operatorname{IgG}}$ \\
\hline \multicolumn{4}{|l|}{ Controls } \\
\hline 1 & 0 & \multirow{5}{*}{ 9S } & 86 \\
\hline 2 & 0 & & 115 \\
\hline 3 & 1 & & 140 \\
\hline 4 & 0 & & 207 \\
\hline 5 & 0 & & 232 \\
\hline \multicolumn{4}{|l|}{ Patients } \\
\hline & 2 & $14 S 21 S$ & 759 \\
\hline & 3 & $13 S 15 S 20 S$ & 547 \\
\hline & 3 & $14 S 15 S>15 S$ & 600 \\
\hline & 4 & $8 \mathrm{~S} 9 \mathrm{~S} 10 \mathrm{~S} 17 \mathrm{~S}$ & 636 \\
\hline & & $9 S 11 S 20 S$ & 477 \\
\hline 5 & 2 & $9 S 11 S$ & 338 \\
\hline \multicolumn{4}{|c|}{ (following plasmapharesis) } \\
\hline \multicolumn{4}{|l|}{ Case 3} \\
\hline Plasma & 3 & $14 S 15 S>15 S$ & 600 \\
\hline PEG precipitate & 3 & $15 S 18 S 33 S$ & 600 \\
\hline PEG supernate & 0 & - & 0 \\
\hline
\end{tabular}

fractionation of an untreated solution of polyvalent IgG (Blood Products Laboratory (BPL), Elstree). Compared with fractionation of the solution of $\mathrm{IgG}$, which showed a single peak of molecular weight $150 \mathrm{kD}$, the PEG precipitated IgG from case 4 contained a broad high molecular weight band up to $1000 \mathrm{kD}$. Similar results were found on studying the PEG precipitates of the other patients, and to a lesser extent in two of the normal controls, though less material was precipitated.

Fractionation of a PEG precipitate of the IgG solution (BPL) showed minimal PEG precipitation of IgG $(0.1 \%)$ with no high molecular weight component.

\section{ANALYTICAL ULTRACENTRIFUGATION OF FRESH} UNTREATED PLASMA (table 1)

Ultracentrifugation of untreated fresh plasma from the five patients showed multiple peaks of high molecular weight material ranging from $8 \mathrm{~S}$ to $21 \mathrm{~S}$ (sedimentation coefficients in plasma). Ultracentrifugation of plasma from five normal controls did not show any high molecular weight components in four subjects and only a single $9 \mathrm{~S}$ peak in one.

The plasma of case 3, which contained three high molecular weight peaks of 14S, 15S, and $>15 S$ was PEG precipitated and the precipitate and the supernate analysed by ultracentrifugation. The PEG precipitate contained three high molecular weight peaks (15S, $18 \mathrm{~S}$, and $33 \mathrm{~S}$, sedimentation coefficients in saline), while the supernatant plasma contained no high molecular weight material. Sedimentation coefficients in plasma and saline are not comparable as the higher viscosity of plasma results in a reduced sedimentation velocity and hence a lower sedimentation coefficient.

ANALYSIS OF PEG PRECIPITATES AND FRESH UNTREATED PLASMA BY AFFINITY

CHROMATOGRAPHY (table 2)

A fibronectin coupled sepharose gel was prepared and used to affinity purify a polyvalent sheep anti-human fibronectin antiserum. The resultant purified antibody was itself coupled to activated sepharose for use as a fibronectin immunoaffinity gel. About half of 
Table 2 Affinity chromatography of fibronectin and IgG from plasma and PEG precipitates (using an antifibronectin immunoaffinity gel).

\begin{tabular}{|c|c|c|c|c|}
\hline Sample & Protein & Load $(\mu g)$ & $\begin{array}{l}\text { Recovery in } \\
\text { glycine }(\mu g)\end{array}$ & $o_{o}$ Retained \\
\hline $\begin{array}{l}\text { Purified fibronectin } \\
\text { IgG solution }\end{array}$ & $\begin{array}{l}\text { Fibronectin } \\
\text { IgG } \\
\text { Fibronectin } \\
\text { IgG }\end{array}$ & $\begin{array}{r}390 \\
0 \\
0 \\
2370\end{array}$ & $\begin{array}{r}189 \\
0 \\
0 \\
0\end{array}$ & $\begin{array}{l}0 \\
0\end{array}$ \\
\hline $\begin{array}{l}\text { Case } 1 \text { PEG } \\
\text { precipitate }\end{array}$ & $\begin{array}{l}\text { Fibronectin } \\
\text { IgG }\end{array}$ & $\begin{array}{l}1500 \\
1440\end{array}$ & $\begin{array}{l}131 \\
105\end{array}$ & 7.0 \\
\hline $\begin{array}{l}\text { Case } 5 \text { PEG } \\
\text { precipitate }\end{array}$ & $\begin{array}{l}\text { Fibronectin } \\
\text { IgG }\end{array}$ & $\begin{array}{l}699 \\
623\end{array}$ & $\begin{array}{r}319 \\
75\end{array}$ & $12 \cdot 0$ \\
\hline $\begin{array}{l}\text { Control PEG } \\
\text { precipitate }\end{array}$ & $\begin{array}{l}\text { Fibronectin } \\
\text { IgG }\end{array}$ & $\begin{array}{l}300 \\
147\end{array}$ & $\begin{array}{r}149 \\
5\end{array}$ & 3.5 \\
\hline $\begin{array}{l}\text { Case } 5 \\
\text { plasma }\end{array}$ & $\begin{array}{l}\text { Fibronectin } \\
\text { IgG }\end{array}$ & $\begin{array}{r}222 \\
20,000\end{array}$ & $\begin{array}{r}70 \\
259\end{array}$ & $1 \cdot 3$ \\
\hline $\begin{array}{l}\text { Control } \\
\text { plasma }\end{array}$ & $\begin{array}{l}\text { Fibronectin } \\
\text { IgG }\end{array}$ & $\begin{array}{r}670 \\
11,000\end{array}$ & $\begin{array}{r}241 \\
34\end{array}$ & 0.3 \\
\hline
\end{tabular}

The percentage of $\mathrm{IgG}$ retained by the gel is calculated from the amount eluted divided by the amount loaded onto the gel. The gel retained purified fibronectin but not IgG.

the purified fibronectin was retained by this gel and was eluted with 0.5 molar glycine ( $\mathrm{pH} 2.5)$. The gel was saturable with fibronectin and therefore the percentage of fibronectin retained decreased when the initial load was in excess. IgG loaded on to the gel appeared in the breakthrough with no elution of IgG during subsequent treatment of the gel with glycine. Thus the gel was specific for fibronectin and had no affinity for IgG.

PEG precipitate from two patients was passed through an uncoupled sepharose gel column to exclude non-specific adsorption of IgG by sepharose, and the eluate was loaded on to the anti-fibronectin antibody immunoaffinity gel. Elution of the column with 0.5 molar glycine yielded demonstrable amounts of IgG in addition to fibronectin. The column also retained small quantities of IgG from the PEG precipitate of a normal control subject. To determine if the column retained any IgG from untreated plasma, fresh plasma samples from a patient and a control were applied to the antifibronectin antibody column. IgG was retained from both plasmas but in greater amounts from the patient plasma (table 2).

The plasma of case 5 was examined before and after plasmapheresis. The disappearance of a $20 \mathrm{~S}$ component from the plasma was associated with a reduction in PEG IgG from $477 \mathrm{mg} / 1$ to $338 \mathrm{mg} / 1$ (table 1 ).

\section{Discussion}

In patients with myeloproliferative disorders high concentrations of plasma PEG precipitable IgG are suggestive of complexed high molecular weight IgG, possibly in the form of immune complexed IgG. ${ }^{5}$ Examination of plasma PEG precipitates by exclusion chromatography confirmed the presence of IgG with a high molecular weight profile. This finding may have been artefactual, however, as PEG may induce aggregation of $\mathrm{IgG}^{89}$ Examination of the molecular weight profile of PEG IgG should therefore be interpreted with caution. In view of this, fresh untreated plasma was examined by analytical ultracentrifugation and this confirmed that patients with myeloproliferative disorders have abnormal circulating high molecular weight material in the absence of any artefacts due to PEG precipitation. Furthermore, PEG precipitated the high molecular weight components, leaving a PEG plasma supernate free of such material.

High concentrations of PEG precipitable fibronectin and IgG may be due to complex formation between these two proteins. ${ }^{5}$ Fibronectin is capable of binding to a variety of plasma proteins, ${ }^{10}$ and complex formation between fibronectin and aggregated IgG has been suggested by others. ${ }^{11-13}$ Further evidence for complex formation between fibronectin and IgG was obtained in our study by examining plasma and PEG precipitates by immunoaffinity chromatography. An anti-fibronectin gel retained IgG from patients' plasma and PEG precipitates, and to a lesser degree from normal plasma and PEG precipitates. As the gel had no affinity for IgG its retention is highly suggestive of complex formation with the retained fibronectin. Rheumatoid factor activity has been reported in some patients with primary myelofibrosis $^{12}$ and the IgG present in the eluates might theoretically have been IgG which bound specifically with the sepharose coupled sheep antibody. No rheumatoid factor activity, however, was identifiable in the plasmas examined, though small amounts of IgG rheumatoid factor and anti-idiotypic antibody can not be excluded.

Immune complexes must reach a critical size to be removed by the reticuloendothelial system. When antibody affinity is low or there is antigen excess, the antigen-antibody network is small and elimination is slow. ${ }^{14}$ The size of the complexes, and hence their clearance, may be increased by opsonisation by other proteinsfor example, complement or rheumatoid factor. ${ }^{15}$ Opsonisation of immune complexes by fibronectin may be a further means of increasing the size of immune complexes. Another possibility is an auxiliary clearance mechanism for immune complexes via macrophage fibronectin receptors. ${ }^{16}$

In conclusion, abnormal circulating high molecular weight IgG is present in the plasma of patients with myeloproliferative disorders. The results of PEG precipitation and analytical ultracentrifugation suggest that this material is IgG in a high molecular weight complex form. Examination of plasma by immunoaffinity chromatography supports our previous evidence for complex formation between IgG and fibronectin. Further studies are necessary to confirm complex formation between fibronectin and IgG and to evaluate the importance of this phenomenon not only in myeloproliferative disorders but also in other disorders characterised by immune complex formation. T P Baglin was supported by the Leukaemia Research Fund.
The work was supported in part by a grant from the United The work was supported in part by a grant from the United Lewin for calculation of ultracentrifugal sedimentation coefficients. 1 Lewis CM, Pegrum GD. Immune complexes in Haematol 1978;39:233-9.

2 Cappio FC, Vigliani R, Novarino A, Camussi G, Campana D, Gavosto F. Idiopathic myelobfibrosis: a possible role for immune-complexes in the pathogenesis of bone marrow fibrosis. Br J Haematol 1981;49:17-21 
3 Gordon BR, Coleman M, Kohen P, Day NK. Immunological abnormalities in myelofibrosis with activation of logical abnormalities in myelofibrosis with action.

4 Vellenga E, Mulder NH, The TH, Nieweg HO. A study of the cellular and humoral immune responses in patients with myelofibrosis. Clin Lab Haematol 1982;4:239-46.

5 Baglin TP, Simpson AW, Price SM, Boughton BJ. The composition of immune-complexes and their relationship to plasma fibronectin in chronic myeloproliferative disorders. J Clin Pathol 1987;40:1468-71.

6 Axen R, Porath J, Ernback S. Chemical coupling of peptides and proteins to polysaccharides by means of cyanogen halides. Nature 1967;214:1302-4.

7 Vuento N, Vaheri A. Purification of fibronectin from human plasma by affinity chromatography under non-denaturing plasma by affinity chromatography und

8 Cooper KM, Moore M. Critical aspects of immune complex assays employing polyethylene glycol. J Immun Methods assays employing

9 Hack CE. $A$ second look at immune complex assays. Amsterdam: Krips Repro Meppel, 1984.

10 Yamada KM, Owen K. Fibronectin-adhesive glycoproteins of cell surface and blood. Nature 1978;275:179-84

11 Carter SD, Scott DL, Elson CJ. Fibronectin binding with immunoglobulin aggregates and its association

2 Rondeau E, Solal-Celigny P, Dhermy D, et al. Immune disorders in alal-Celigny $\mathrm{P}$, Dhermy $\mathrm{D}$, et al. Immune disorders in agnogenic myeloid metaplasia:

13 Scott DL, Carter SD, Coppock JS, Robinson M, Walton $\mathrm{KW}$. Differences between plasma and synovial fluid fibronectin. Rheumatol Int 1985;5:49-j4

14 Mannick M, Arend MP, Hall AP, Gilliland BC. Studies on antigen-antibody complexes. I. Elimination of soluble complexes from rabbit circulation. $J$ Exp Med 1971;133:713-39.

15 Van Snick JL, Van Roost E, Markowetz B, Cambiaso CL, Masson PL. Enhancement of IgM rheumatoid factor of in vitro ingestion by macrophages and in vivo clearance of aggregated IgG or antigen-antibody complexes. Eur $J$ Immunol 1978;8:279-85.

16 Bevilacqua MPI, Amrani D, Mosesson MW, Bianoco C Receptors for cold insoluble globulin (plasma fibronectin) on human monocytes. J Exp Med 1981;153:42-60. 